\title{
Increased Environmental Requirements for Energy Objects in the Central Ecological Area of the Baikal Natural Territory: Problems and Condition for Implementation
}

\author{
Elena P. Maysyuk ${ }^{1,2, *}$ \\ ${ }^{1}$ Melentiev Energy Systems Institute SB RAS, 130 Lermontov, Irkutsk, Russia \\ 2 Irkutsk Scientific Center SB RAS, 134 Lermontov, Irkutsk, Russia
}

\begin{abstract}
The most important document regulating the use of natural resources in the territories adjacent to the lake Baikal in Russia became the federal law No. 94 "On the protection of the lake. Baikal" from 1 May 1999. A list of prohibited activities has been approved for the central ecological area which now again discuss. Taking into account the categorization of objects that have a negative impact on the environment, the energy objects of the central ecological area are assigned to categories II and III. And in case of changes concerning of categorization in the list of prohibited activities, it means that operation of energy objects will prohibited. The main environmental problem of the energy sector is the use of coal and the presence of a hazard class 1 substance in the emissions. To achievement environmental requirements, it is necessary to replace coal with alternative environmentally friendly types of energy carriers (natural gas and electricity). In order to implement the increased requirements for energy objects, it is necessary to develop a special package of normative legal acts and government support measures, including significant financial costs, focused on this territory.
\end{abstract}

\section{Introduction}

Currently for the protection of the lake. Lake Baikal along with the fundamental legislative acts (the UN Convention and The law "On the protection of the 1 Lake Baikal") [1, 2] the Governments of Russia and the subjects of the Russian Federation have developed a series of documents regulating the protection of lake Baikal and the socio-economic development of the adjacent territory.

According to the recommendations of the UNESCO Committee, along with the adoption of the law "On the protection of the Lake Baikal" (1999), the boundaries of the world heritage site with an area of 8.8 million hectares were established, the Baikal pulp and paper mill was closed (in 2013) and other activities were done.

One of the results of the adoption of the law "On the protection of the 1 Lake Baikal" was zoning with the formation of the Baikal natural territory and release three ecological areas: central, buffer and area of atmospheric influence.

Increased environmental requirements in the central ecological area are mostly associated with the presence of specially protected natural territories in this area: national parks, reserves, reserves, etc. Such restrictions are reflected in Federal law No. 33 of 14.03.1995 "On specially protected natural territories" [3]. Outside the boundaries of protected areas, a special mode of life and nature management is regulated by the law on the protection of the Lake Baikal.
It was determined that in the central ecological area it is necessary to reorient economic activities and existing infrastructure to ecologically acceptable types, which will ensure a harmonious combination of the life of the population and the functioning of economic objects with the environment.

It should be noted that the boundaries of the World Heritage Site do not include five urbanized, industrially developed territories (Baikalsk, Slyudyanka, Kultuk, Babushkin, Severobaikalsk). Moreover, these settlements include in central ecological area and it is in these territories that the largest industrial enterprises are located, where the most active economic activity is carried out.

\section{Basis position}

For the Central ecological zone by the Government of the Russian Federation in accordance with the Federal law "On the protection of the Lake. Baikal" was developed and approved by the Resolution of the Government of the Russian Federation No. 643 of August 30, 2001 [4] the list of prohibited activities, which eventually amounted to more than 50 types, and changes in this list are currently being discussed [5].

In the current Resolution No. 643, the list of activities prohibited in the central ecological area of the Baikal natural territory that relate directly or indirectly to energy systems includes the following [4]:

\footnotetext{
* Corresponding author: maysyuk@isem.irk.ru
} 
- Extraction of crude oil and natural gas.

- Production of sources of autonomous power supply.

- Electricity production with a unit capacity of power plants over $100 \mathrm{MW}$, as well as activities for the supply of energy produced in the central ecological area of the Baikal natural territory, outside this area.

- Energy production at nuclear power plants.

- Construction of main oil pipelines, gas pipelines and other product pipelines, with the exception of gas pipelines for local gas supply.

- Construction of buildings and structures for metallurgical, chemical and petrochemical enterprises, coal-fired boiler houses and thermal power plants, with the exception of overhaul, reconstruction, modernization of coal-fired boiler houses and thermal power plants, as well as their distribution networks.

- Wholesale trade in solid, liquid and gaseous fuels and related products.

- Neutralization of production and consumption waste by incineration without purification of emissions to standard quality.

- Activities for the provision of housing and communal services during the operation of sanatorium and resort and recreational complexes without structures that provide wastewater treatment and emissions of harmful substances into the atmospheric air up to the approved standards.

The draft Resolution of the Government of the Russian Federation of 2020 "On Approving the List of Activities Prohibited in the central ecological area of the Baikal Natural Territory" is currently changes made, which are primarily related to the categorization of objects that have a negative impact on the environment. The criteria for assigning objects to different categories are determined by the Resolution of the Government of the Russian Federation No. 1029 of September 28, 2015 "On approval of criteria for classifying objects that have a negative impact on the environment as objects of categories I, II, III and IV" [6].

\subsection{Problems}

Research carried out at the Melentiev Energy Systems Institute SB RAS revealed that about 100 energy objects of various capacities currently operate in the central ecological area, which use coal, firewood, liquefied natural gas, fuel oil, as well as electricity for heating [7]. By classifying them based on categorization criteria, energy objects can be classified into categories II (large boiler houses, Baikal CHP) and III (the majority of lowpower boiler houses).

At the same time, objects that have an insignificant negative impact on the environment and objects that are not included in group II or IV are classified as objects of category III. Thus, category IV includes [6] stationary sources of environmental pollution, the mass of pollutants in emissions into the atmosphere of which does not exceed 10 tons per year, in the absence of substances of hazard classes I and II, radioactive substances. Also, these sources should not discharge pollutants into centralized water disposal systems and the environment. In addition, category IV objects include facilities for providing electric energy, gas and steam (using equipment with a design heat capacity of less than 2 Gcal perhour when consuming gaseous fuel).

Taking into account the fact that the boiler houses of the central ecological area use mainly coal as fuel and even with small volumes of emissions, they emit benz(a)pyrene - a substance of the 1st hazard class, respectively, and belong to the III category. If a new Resolution on the list of prohibited activities in the central environmental area is approved, these objects will be banned not only for construction and reconstruction, but also for operation.

As a result, the increased environmental requirements for the central ecological area are mainly prohibitive and are determined by the list of prohibited economic activities and a special regime of environmental management for the population.

The main environmental problem in the energy sector of the central ecological area is the use of coal $(70 \%$ of heat sources operate on coal). Under the current Resolution No. 643, even a ban on the construction of new coal-fired boiler houses will not solve this problem, and the allowed reconstruction and modernization of existing morally and technically out-dated energy objects (equipment wear reaches $80 \%$ ) will not allow achieving the maximum effect on reducing emissions. In addition, up to $60 \%$ are emissions from low-power boiler houses without proper cleaning of particular matter.

In this regard, it should be noted that the regulation of permissible emissions at the level of the government of the Russian Federation, both in Order No. 63 of March 5, 2010 [8] and in Order No. 83 of February 21, 2020 [9] provides for only two pollutants: sulfur and nitrogen oxides. Permissible emissions of harmful substances into the atmosphere from objects of all types of economic activity (not only energy objects) are developed for three basins of Lake Baikal - in Table 1.

Table 1. Standards for permissible air emissions for three basins of the Lake. Baikal during the year, thousand tons

\begin{tabular}{|c|c|c|}
\hline \multirow{2}{*}{ Territory } & \multicolumn{2}{|c|}{ Pollutant } \\
\cline { 2 - 3 } & $\begin{array}{c}\text { Sulphur } \\
\text { oxides }\end{array}$ & $\begin{array}{c}\text { Nitrogen } \\
\text { oxides }\end{array}$ \\
\hline Baikal natural territory, total & 6.4 & 3.27 \\
\hline Southern basin of Lake Baikal & 4.0 & 2.1 \\
\hline Middle basin of Lake Baikal & 1.2 & 0.63 \\
\hline Northern basin of Lake Baikal & 1.2 & 0.54 \\
\hline
\end{tabular}

It should be noted that the standards for basins developed in Resolution No. 63 of March 5, 2010 require clarification in order to understand the permissible impact standards, for example, in the southern basin, the standards are provided for two ecological areas, while large industrial enterprises 
operate on the territory of the buffer ecological area in the southern part of Lake Baikal, and under certain meteorological conditions (as for the area of atmospheric influence), emissions can flow to the lake's water aquatory.

When coal is burned, the main impurity (80-90\%) from the emission is particulate matter which directly enters in the surface layer and are washed out with precipitation (snow, rain) into the Lake Baikal. In fact, in the central ecological area, the emission of particulate matter from energy objects is predominant, and their rationing is absent.

At the same time, comparing the existing emission and standards, we can state the fact that only from energy objects to the Northern and Southern basins of the lake. Baikal receives more than $50 \%$ of emissions of sulfur oxides, and depending on the fuel burned and the winter period, this emission is close to or cab exceeds the norms [10].

In general, the environmental requirements for the central ecological area can be formulated as minimizing the impact on all elements of the environment.

\subsection{Condition for implementation}

To meet the environmental requirements for energy objects in the central ecological area, various measures and directions were developed to reduce emissions and waste generation $[10,11]$.

Among the possible directions are the modernization of coal-fired boiler houses; the replacement of coal with alternative environmentally friendly fuels (wood fuel, natural gas); the use of electricity for heating; and the use of renewable energy sources. For their implementation, there are certain conditions associated with the problems of legislation for a specially protected natural area or with high economic costs.

Modernization of coal-fired boiler houses, including cleaning equipment, will significantly reduce the load on the environment. However, taking into account the newly introduced restrictions on the categorization of energy objects (they will be assigned to categories II and III), their operation should be prohibited. In this case, the alternative to modernizing large coal-fired boiler houses will be to replace coal with environmentally friendly types of energy carriers (natural gas and electricity). Thus, there are all favourable conditions for replacing coal with natural gas, from the presence of a large gas condensate field of natural gas on the territory of the Irkutsk oblast, to qualified personnel for the use of gas fuel, etc. However, solving of this issue requires amendments to the legislation, including the list of prohibited activities, which includes "... the construction of main oil pipelines, gas pipelines and other product pipelines, with the exception of gas pipelines for local gas supply". In addition, the economic justification for the use of natural network gas with estimates of the rational volume of gas consumption in power objects (within the range of 175-190 thousand tons of fuel equivalent) and competitive prices for different categories of boiler houses, taking into account changes in efficiency, shows the need to use state support measures, since, in most cases, the implementation of such measures requires significant investment [12-13]. Small-capacity gas-fired boilers have great advantages, first of all, low emissions into the atmosphere, attributing them to category IV, which has its own preferences in terms of exemption from obligations to calculate emission standards and payments for emissions.

Another attractive and most feasible direction of reducing the anthropogenic load from energy objects to the environment is the use of electricity for heat supply. This direction is the most environmentally attractive, since the operation of such energy sources is completely no emissions, discharges and waste to the environment. Estimates of the potential amount of electricity to replace coal in boiler houses show that such measures are highly feasible. Competitive electricity tariffs for the implementation of this event are estimated at 1 RUB per $\mathrm{kWh}$ and the need for boiler houses in the central ecological area about 1300-1400 million kWh [11]. Currently, tariffs are significantly higher in the studying territory, especially within central ecological area of the Republic of Buryatia.

\section{Conclusions}

To meet the environmental requirements for energy objects in the central ecological area, it is preferable to use alternative energy carriers for heat energy production instead of coal.

The most preferable option is to replace coal with natural gas. The rational volume of gas consumption in power facilities is estimated at 175-190 thousand tons of fuel equivalent. The main condition for implementation is the construction of an export gas pipeline from Russia (through the territory of the Irkutsk oblast) to China via Mongolia and amendments to existing legislation or the organization of low-tonnage production of liquefied natural gas.

The most feasible currently is the use of electricity for heating purposes. According to the authors ' estimates, the potential volume of electricity for replacing coal in the Central ecological zone boilers is 1.3 billion $\mathrm{kWh}$ per year, but the competitive electricity tariff should be $1 \mathrm{RUB} / \mathrm{kWh}$, which is several times lower than the current tariffs.

Thus, the functioning of energy objects in the central ecological area is spontaneous and does not correspond to the ecological significance of the territory. And, if the increased environmental requirements for energy objects in the existing legislation are formulated in the form of minimizing the impact on all elements of the environment, then the problems of meeting such requirements are associated with the need to develop a special package of normative legal acts, of state support measures focused on this territory, including significant financial costs.

The study was carried out in the framework of integration program of the ISC SB RAS, State Registration N.: AAAA-A17-117041250054-8 


\section{References}

1. World Heritage Site Documentation (Natural Nominations). World Heritage Committee. Twentieth Regular Session 2-7 December 1996, Merida, Mexico. Prepared by the International Union for Conservation of Nature (IUCN) 1996 Gland, Switzerland, October 10, 1996. World Heritage Nomination - Technical Assessment of the International Union for Conservation of Nature (IUCN) "Lake Baikal Basin (Russia)", (1996)

2. Federal Law of the Russian Federation No 94 "On the Protection of the Lake Baikal". Approved by Decree of the President of the Russian Federation on May 1, 1999. Access by http://ru.convdocs.org/docs/index-37629.html (1999)

3. Federal law No. 33 of March 14, 1995 "On specially protected natural territories" (with amendments and additions), Access https://base.garant.ru/10107990/ (1995)

4. Resolution of the Government of the Russian Federation of August 30, 2001 No. 643 "On approval of the list of activities prohibited in the central ecological zone of the Baikal natural territory" (with amendments and additions). Access by https://base.garant.ru/2158203/ (2001)

5. The list of activities prohibited on Baikal will be amended: expert opinion. Access by https://i38.ru/baykal-obichnie/v-perechen-vidovdeyatelnosti-zapreschennich-na-baykale-vnesutizmeneniya-mnenie-eksperta (2020)

6. Resolution of the Government of the Russian Federation No. 1029 dated September 28, 2015 "On approval of the criteria for classifying objects that have a negative impact on the environment to objects of categories I, II, III and IV." Access by http://www.consultant.ru/document/cons doc LAW $186693 /(2015)$

7. B.G. Saneev, I. Yu. Ivanova, E.P. Maysyuk, T.F. Tuguzova, R.A. Ivanov. Energy infrastructure of the central ecological area: impact on the environment and ways to reduce it, Geography and natural resources J., 5, 218224 (2016)

8. Order of the Ministry of Natural Resources and Ecology of the Russian Federation No. 63 of March 5, 2010 "On approval of standards for maximum permissible impacts on the unique ecological system of Lake Baikal and the list of harmful substances, including substances belonging to the categories of especially hazardous, highly hazardous, hazardous and moderately hazardous for the unique ecological system of Lake Baikal" Access by https://base.garant.ru/12176656/ (2010)

9. Order of the Ministry of Natural Resources and Ecology of the Russian Federation dated February 21, 2020 No. 83 "On approval of standards for maximum permissible impacts on the unique ecological system of Lake Baikal and the list of harmful substances, including substances belonging to the categories of especially hazardous, highly hazardous, hazardous and moderately hazardous for unique ecological system of Lake Baikal". (Registered 23.04.2020 No. 58181) Access by http://publication.pravo.gov.ru/Document/View/ (2020)

10. B.G. Saneev, I. Yu. Ivanova, E.P. Maysyuk, T.F. Tuguzova, R.A. Introduction of Environmental Measures in the Heat Power Industry of the central Ecological zone of Baikal Natural territory, Ecology and Industry of Russia J., 22 (7), 20-25 (2018)

11. B.G. Saneev, I. Yu. Ivanova, E.P. Maysyuk, A.K. Izhbuldin, The main directions of solving energy-related environmental problems in the central ecological zone of the Baikal natural territory, Geography and natural resources IOP Conf. Ser.: Earth Environ 381, 012082 (2019)

12. A. K. Izhbuldin, Impact of gas supply system development scenarios on natural gas demand in the Baikal region, E3S Web of Conferences, 77, (2019)

13. B.G. Saneev, I. Yu. Ivanova, E.P. Maysyuk, A.K. Izhbuldin, T.F. Tuguzova. Conversion of boiler houses of the central ecological zone of the Baikal natural territory to gas: prerequisites, effects, barriers, Geography and natural resources J., 6, 27-31 (2016) 